\title{
Використання променевої артерії в лікуванні пацієнтів з ішемічною хворобою серця в умовах штучного кровообігу
}

\author{
Варбанець С. В., Цвик А. С., Пукас О. Ю., Руденко Н. М.
}

\author{
ДУ «Науково-практичний медичний центр дитячої кардіології та кардіохірургії МОЗ України» (Київ)
}

\begin{abstract}
В даній роботі представлено досвід НПМЦДКК з використання променевої артерії (ПА) у лікуванні пацієнтів з IXC в умовах штучного кровообігу. Метою даної роботи було висвітлити досвід застосування ПА в якості графта для аортокоронарного шунтування (АКШ) в умовах штучного кровообігу (ШК), проаналізувати власні результати та можливі ускладнення при використанні ПА, довести безпечність, ефективність та універсальність ПА як судинного графта.

В роботі представлена методика виділення ПА та її використання в якості судинного графта. Для висвітлення теми було проаналізовано 42 хірургічні втручання, в яких використовувалась ПА. Середній вік па-

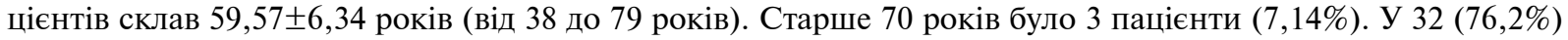
пацієнтів супутнім діагнозом був цукровий діабет. Хронічні обструктивні захворювання легень (ХОЗЛ) було діагностовано в $32(76,2 \%)$ пацієнтів. Індекс маси тіла $>30$ виявлено у $19(45,2 \%)$ пацієнтів (від 23,95 до 39,06). Середня фракція викиду (ФВ) у пацієнтів досліджуваної групи склала 52,4\% (від 30 до 64\%).

Результати використання ПА в якості графта для лікування пацієнтів з IXC порівняно з використанням інших графтів демонструє ряд переваг і низький рівень ускладнень.

Використання ПА в якості судинного графта для АКШ можна вважати безпечним та ефективним, ПА $€$ універсальним графтом. ПА можна використовувати у пацієнтів із повторними хірургічними втручаннями, у яких великі підшкірні вени (ВПВ) відсутні, у пацієнтів із варикозною хворобою нижніх кінцівок або в пацієнтів з ожирінням, цукровим діабетом і ХОЗЛ.
\end{abstract}

Ключові слова: променева артерія, судинний графт, аортокоронарне шунтування, IХС.

Незважаючи на перкутанні коронарні втручання, АКШ вважається основним ефективним методом лікування IXC для пацієнтів з багатосудинним ураженням коронарних артерій (KА) [1]. Використання лівої внутрішньогрудної артерії (ЛВГА) для шунтування передньої міжшлуночкової гілки системи лівої коронарної артерії (ПМШГ ЛКА) покращило результати коронарного шунтування (КШ) [2] і на сьогодні є золотим стандартом у самій методиці шунтування коронарних судин [3]. Стосовно використання графтів у системі правої коронарної артерії (ПКА), огинаючу гілку системи лівої коронарної артерії (ОГ ЛКА) та діагональну гілку передньої міжшлуночкової артерії (ДГПМА ЛКА) думки суперечливі. Тривалий час ВПВ використовували як графт для шунтування КА системи ПКА, ОГ ЛКА, ДГПМА ЛКА з одномоментним використанням ЛВГА для шунтування ПМШГ ЛКА, незважаючи на досить високий відсоток порушення прохідності венозних графтів: 20-40\% за рік [4]. Одноцентрові дослідження вказують, що додаткові артеріальні графти, крім ЛВГА, покращують показники виживання порівняно з групою пацієнтів, яким було використано лише один артеріальний графт [5]. У дослідженні Robert F. Tranbaugh та ін. порівнювали 10-річну виживаність пацієнтів, яким, крім одномоментного використання ЛВГА для шунту- вання ПМШГ ЛКА, було використано променеву артерію (ПА), праву ВГА та ВПВ. Летальність при використанні ПА становила 20\%, при використанні правої ВГА - 28\% та при використанні ВПВ - 37,2\% [4].

Мета роботи - висвітлити досвід застосування ПА в якості графта для АКШ в умовах штучного кровообігу (ШК), проаналізувати власні результати та можливі ускладнення при використанні ПА, довести безпечність, ефективність та універсальність ПА як судинного графта.

Матеріали та методи. На базі ДУ «НПМЦДКК МОЗ України» за період з 1.01.2017 по 15.02.2018 було прооперовано 42 пацієнти з використанням ПА в якості АГ для АКШ.

Переважну більшість пацієнтів становили особи чоловічої статі - 37 (88,01\%), пацієнтів жіночої статі було

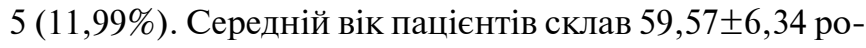
ків (від 38 до 79 років). Старше 70 років було 3 пацієнти (7,14\%). У 32 (76,2\% ) пацієнтів супутнім діагнозом був цукровий діабет. Хронічні обструктивні захворювання легень (ХОЗЛ) було діагностовано в $32(76,2 \%)$ пацієнтів. Індекс маси тіла $>30$ виявлено у $19(45,2 \%)$ пацієнтів (від 23,95 до 39,06). Середня фракція викиду (ФВ) у пацієнтів досліджуваної групи становила 52,4\% (від 30 до 64\%). Розподіл пацієнтів за NYHA: NYHA I - 5 


\section{Таблиця 1}

Розподіл пацієнтів згідно з типом хірургічного втручання

\begin{tabular}{lcc} 
Тип втручання & $\mathbf{n}$ & $\mathbf{\%}$ \\
\hline Ізольоване АКШ & 35 & 83,2 \\
\hline АКШ з протезуванням АК & 2 & 4,8 \\
\hline АКШ з пластикою МК & 4 & 9,6 \\
\hline АКШ з протезуванням МК & 1 & 2,4 \\
\hline Всього & $\mathbf{4 2}$ & $\mathbf{1 0 0}$
\end{tabular}

(11,9\%) пацієнтів, NYHA II - 18 (42,85\%), NYHA III $19(45,25 \%)$ пацієнтів відповідно.

Із 42 хірургічних втручань 3 використанням ПА в якості судинного графта в 35 випадках було виконано ізольоване АКШ, у 2 випадках - АКШ + протезування аортального клапана (ПАК), у 4 випадках виконано АКШ + пластика мітрального клапана (МК), в одному випадку - АКШ + протезування (ПМК) (табл. 1).

Методика виділення ПА та ї̈ використання в якості судинного графта. Всім пацієнтам було проведено оперативне втручання стандартним доступом через серединну стернотомію з використанням апарату штучного кровообігу та гіперкаліємічною кров'яною кардіоплегією в умовах помірної гіпотермії. Одномоментно виконували екстраплевральну експозицію ВГА та виділення ПА. Перед виділенням ПА всім пацієнтам було проведено пробу Аллена: час відновлення кровотоку по кисті після повного перетиснення променевої та ліктьової артерії в нормі становить не більше 6 секунд. У всіх випадках було використано ПА з недомінантної руки. Для додаткового контролю перфузії крові в кінцівці використовувалася пульсоксиметрія. Виділення ПА виконували відкритим способом через поздовжній розріз шкіри. Орієнтирами для оптимальної експозиції ПА під час розрізу слугували: проксимально - сухожилля двоголового м'яза плеча, дистально - сухожилля променевого м'яза-згинача зап'ястя та шилоподібний відросток променевої кістки. Розріз шкіри проводили на 1 см латеральніше місця пальпації сухожилля двоголового м'яза плеча, дистально - до проміжку між сухожиллям променевого м'яза-згинача зап'ястя та шилоподібним відростком променевої кістки. Після сепарування підшкірно жирової клітковини для експозиції розсікали фасцію між плечо-променевим м'язом і променевим м'язом-згиначем зап'ястя. За допомогою розширювача м'язи розводили, у такий спосіб бічний шкірний нерв передпліччя та поверхневий нерв передпліччя знаходилися латерально від зони хірургічних маніпуляцій під час виділення ПА, цим самим мінімізувався ризик ушкодження вказаних нервів. Бічний шкірний нерв передпліччя іннервує передньо-бокову поверхню передпліччя, поверхневий нерв передпліччя іннервує долонну поверхню великого пальця кисті, тильну поверхню кисті, великого, вказівного та медіальну частину середнього пальця. ПА виділяли на ніжці, для мінімізації вірогідності спазму та механічного ушкодження використовували лігатури, які проводили під ПА та променеві вени (ПВ), що забезпечувало оптимальну експозицію. Гілки ПА обробляли за допомогою гемостатичних кліпів і діатермокоагуляції. Перед відсіканням ПА перетискалася до повної зупинки кровоточу, перевірялися показники пульсоксиметрії. Показники сатурації вищі за 90\% і наявність пульсової хвилі вказували на достатній резервний кровіток по ліктьовій артерії. Орієнтирами для місця відсікання слугували: проксимально - променева поворотна артерія, дистально - поверхнева долонна гілка ПА. Проксимальний кінець ПА перев'язували та відсікали. Проводили оцінювання ретроградного кровотоку з дистального кінця, після чого перев'язували та відсікали дистальний кінець артерії. Відразу після виділення ПА промивали інтралюмінально через катетер розчином верапамілу $0,25 \%$, зовнішньо зрошували $2 \%$ розчином папаверину та інтралюмінально промивали $0,9 \%$ розчином натрію хлориду. ПА зберігали в цьому ж розчині до моменту використання в якості графта. Дистальний анастомоз нашивали до коронарної артерії кінець у бік ниткою prolen $8-0$, проксимальний кінець нашивали до аорти prolen $7 / 0$. Культі ПА прошивали додатково ниткою prolen $5 / 0$. Після ретельного гемостазу для попередження компартмент-синдрому шов підшкірної клітковини та фасцій не виконували, лише внутрішньошкірний шов. Бинтування також не використовували з метою попередження ішемічних ускладнень з боку кінцівки.

Результати та обговорення. Середній час перетис-

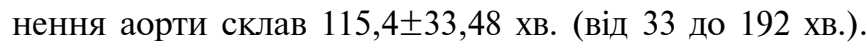
Середня кількість шунтів на одного пацієнта дорівнювала $3,3 \pm 0,87$. У $40(95,2 \%)$ випадках виконано повну артеріальну реваскуляризацію з використанням ПА: у 31 (77,5\%) - з використанням обох ВГА, у 9 (22,5\%) - 3 використанням однієї ЛВГА. У 2 (4,8\%) випадках виконано неповну артеріальну реваскуляризацію: в першому випадку було використано ЛВГА, ПА та ВПВ, у другому - ПА та ВПВ. У $10(23,8 \%)$ пацієнтів ПА використано як другий після ЛВГА артеріальний графт, а в одному випадку - як єдиний артеріальний графт ПМШГ ЛКА.

У 4 (9,5\%) випадках для повної артеріальної реваскуляризації ПА було використано у пацієнтів з IXC i супутніми захворюваннями (ожиріння, цукровий діабет та ХОЗЛ) яК другий артеріальний графт на противагу правій ВГА. У зв'язку з відсутністю ВПВ в одному випадку було використано ПА. У всіх випадках ПА нашивалася при стенозі нативних коронарних артерій $\geq 70 \%$. У табл. 2 вказано, які КА було шунтовано з використанням ПА.

В ранньому післяопераційному періоді під час перебування у відділенні реанімації та IT в усіх пацієнтів не 


\section{Таблиця 2}

КА, шунтовані з використанням ПА

\begin{tabular}{lc} 
КА, шунтовані ПА & Кількість \\
\hline Задня міжшлуночкова гілка системи ПКА & 23 \\
\hline Права коронарна артерія & 2 \\
\hline Задньо-бокова гілка ПКА & 3 \\
\hline $\begin{array}{l}\text { Секвенційно задня міжшлуночкова гілка та зад- } \\
\text { ньо-бокова гілки системи ПКА }\end{array}$ & 4 \\
\hline ПМШГ ЛКА & 1 \\
\hline ДГПМА ЛКА & 1 \\
\hline Артерія тупого краю (АТК) ОГЛКА & 5 \\
\hline Секвенційно АТК ОГЛКА та ДГПМА ЛКА & 1 \\
\hline $\begin{array}{l}\text { Секвенційно АТК ОГЛКА та проміжна гілка } \\
\text { системи ЛКА }\end{array}$ & 2 \\
\hline Всього & 42
\end{tabular}

було змін на ЕКГ порівняно з доопераційними даними. Середня тривалість перебування у відділенні реанімації та IT становила 2,2 2,6 доби (від 2 до 5 діб). 37 пацієнтів потребували інотропної підтримки: 20 (47,6\%) пацієнтів потребували інотропної підтримки допаміном, у середньому 3,2 мкг/кг/Хв. (від 2 до 5 мкг/кг/хв.); 11 (26,1\%) пацієнтів - добутаміном, у середньому 3,2 мкг/кг/хв. (від 2 до 5 мкг/кг/хв.); у комбінації добутаміну та допаміну мали потребу $6(14,2 \%)$ пацієнтів, у середньому добутамін - 3,5 мкг/кг/хв. (від 3 до 5 мкг/кг/хв.) і допамін - 4,1 мкг/кг/хв. (від 3 до 5 мкг/кг/хв.). 32 пацієнтам визначали рівень КФК МВ, середній показник якого склав 71,6 U/L (від 38 до $180 \mathrm{U} / \mathrm{L}$ ).

На госпітальному етапі летальних випадків не було. Не було жодного випадку післяопераційної кровотечі та інфекційних ускладнень грудини.

В усіх випадках моторна функція кінцівки, з якої було виділено ПА, збережена на доопераційному рівні. У $2(4,7 \%)$ випадках спостерігалося транзиторне порушення чутливості в зоні іннервації поверхневого нерва передпліччя. У зв'язку з підвищеною ексудацією 3 післяопераційної рани передпліччя $1(2,4 \%)$ пацієнт потребував хірургічної ревізії рани, джерела кровотечі не було виявлено.

Завдяки отриманим нами результатам можна вважати використання ПА в якості графта безпечним та ефективним у лікуванні IXC. Robert F. Tranbaugh та ін. в 2014 році встановили, що немає значущої різниці в 5-річній прохідності графтів правої ВГА та ПА - 87,4\% та 83,9\% відповідно [6]. При порівнянні 5-річної прохідності графтів ПА і ВПВ показники становили $82 \%$ та 47\% відповідно [7].

Використання обох ВГА є ефективним методом для артеріальної реваскуляризації у пацієнтів з IXC [8]. Однак у пацієнтів із цукровим діабетом, ожирінням та ХОЗЛ використання обох ВГА збільшує ризик виникнення глибоких інфекцій грудини (ГІГ) [9]. Згідно з до- слідженням J. R. Leonard, виникнення ГІГ у групі пацієнтів із використанням обох ВГА та з використанням ЛВГА та ПА становили 5,3\% та 0,6\% відповідно [10].

Таким чином, ПА $є$ альтернативним варіантом другого артеріального графта на противагу правій ВГА для пацієнтів з ожирінням, цукровим діабетом і ХОЗЛ.

Використання ПА у пацієнтів віком понад 70 років не має переваги над використанням ВПВ [4]. Навіть у пацієнтів цієї вікової категорії з варикозною хворобою CEAP III-IV ст. і в пацієнтів із попередніми оперативними втручаннями після виділення ВПВ, ПА може бути альтернативним графтом на противагу ВПВ. Рівень інфекційних ускладнень кінцівок після виділення ВПВ та ПА становить 4,1\% та 1,7\% відповідно [11-12]. У даному дослідженні інфекційних ускладнень після виділення ПА не було.

Висновки. Використання ПА в якості судинного графта для АКШ можна вважати безпечним та ефективним. Методика виділення ПА має невеликий відсоток ускладнень. ПА в якості судинного графта для АКШ $є$ універсальним графтом. ПА можна використовувати як альтернативу правій ВГА для повної артеріальної реваскуляризації у пацієнтів із підвищеним ризиком інфікування грудини. Також ПА може широко використовуватись у пацієнтів із повторними хірургічними втручаннями, у яких ВПВ відсутні, та у пацієнтів із варикозною хворобою нижніх кінцівок.

\section{Література}

1. Total arterial revascularization with internal thoracic and radial artery grafts in triple-vessel coronary artery disease is associated with improved survival / Brian F. Buxton, William Y. Shi, James Tatoulis et al. // J Thorac Cardiovasc Surg. -2014. - Vol. 148. - P. 38-39.

2. Influence of the internal-mammary-artery graft on 10-year survival and other cardiac events / Loop F. D., Lytle B. W., Cosgrove D. M. et al. // N Engl J Med. - 1986. - Vol. 314. P. $1-6$.

3. Taggart D. P., D’Amico R., Altman D. G. Effect of arterial revascularisation on survival: a systematic review of studies comparing bilateral and single internal mammary arteries // Lancet. - 2001. - Vol. 358. - P. 870-5.

4. Coronary Artery Bypass Graft Surgery Using the Radial Artery, Right Internal Thoracic Artery, or Saphenous Vein as the Second Conduit. Society of Thoracic Surgeons / Robert F. Tranbaugh, MD, Thomas A. Schwann, MD, Daniel G. Swistel, MD, et al. // Ann Thorac Surg. 2017. - Vol. 104. - P. 553-9.

5. Timevarying survival benefit of radial artery versus vein grafting: a multiinstitutional analysis / Schwann T. A., Tranbaugh R. F., Dimitrova K. R. et al. // Ann Thorac Surg. - 2014. - Vol. 97. - P. 1328-34.

6 . The second best arterial graft: a propensity analysis of the radial artery versus the free right internal thoracic artery to bypass the circumflex coronary artery / Tranbaugh R. F., Dimitrova K. R., Lucido D. J. et al. //J Thorac Cardiovasc Surg. - 2014. - Vol. 147. - P. 133-40. 
7. Coronary artery bypass grafting using the radial artery: clinical outcomes, patency, and need for reintervention / Tranbaugh R. F., Dimitrova K. R., Friedmann P. et al. // Circulation. - 2012. - Vol. 126 (Suppl. 1). - P. 170-5.

8. Benedetto U., Amrani M., Raja S. G. Guidance for the use of bilateral internal thoracic arteries according to survival benefit across age groups // J Thorac Cardiovasc Surg. 2014. - Vol. 148. - P. 2706-11.

9. Risk factors for mediastinitis after cardiac surgery - a retrospective analysis of 1700 patients / Claudius Diez, Daniel Koch, Oliver Kuss et al. // Journal of Cardiothoracic Surgery. - 2007. - Vol. 2. - P. 23-30.
10. The radial artery: Results and technical considerations / Leonard J. R., Abouarab A. A., Tam D. Y. et al. // Journal of Cardiothoracic Surgery. - 2018. - P. 1-6.

11. Arm Complications After Radial Artery Procurement for Coronary Bypass Operation / Michael A. Greene, MD, and Mark A. Malias, MD, et al. // Ann Thorac Surg. 2001. - Vol. 72. - P. 126-8.

12. Major Leg Wound Complications After Saphenous Vein Harvest for Coronary Revascularization / Christian E. Paletta, MD, David B. Huang, MD, Andrew C. Fiore, MD et al. // Ann Thorac Surg. - 2000. - Vol. 70. - P. 492-7.

\title{
Use of a radial artery in the treatment of patients with ischemic heart disease under cardiopulmonary bypass
}

\author{
Varbanets S., Tsvyk A., Pukas A., Rudenko N. \\ Ukrainian Children's Cardiac Center (Kyiv)
}

In this paper, the experience of UCCC in the use of the radial artery (RA) for on-pump coronary artery bypass grafting $(\mathrm{CABG})$ of patients with coronary artery disease was presented. The purpose of this study was to highlight the postoperative early results and complications of RA conduit usage in the aforementioned group, also prove the safety, efficacy, feasibility of RA conduit application; on top of that, the paper presented the method of RA harvesting. Our study enrolled 42 surgical interventions with RA consuming. The average age of patients was $59.57 \pm 6.34$ years (from 38 to 79 years). The age of 3 patients $(7.14 \%)$ were above 70 years old. $32(76.2 \%)$ patients experienced diabetes mellitus of II type. Chronic obstructive pulmonary disease (COPD) has been diagnosed in 32 (76.2\%) patients. A body mass index $>30$ (23.95 to 39.06$)$ were in 19 $(45.2 \%)$ patients. The mean ejection fraction (EF) in the study group was $52.4 \%$ (30 to $64 \%$ ).

With respect to the comparative results, RA conduit usage demonstrated superior advantages, less complications versus vein grafts.

The RA conduit utilization appears to be a viable, safe, and effective option for a durable CABG. RA can be consumed in patients for redo surgeries in the lack of saphenous veins' grafts, in a group of patients with varicose veins of the lower extremities or obesity, diabetes mellitus and COPD.

Key words: radial artery, conduit, coronary artery bypass grafting, ischemic heart disease. 